\title{
The imbalance of glaciers after disintegration of Larsen-B ice shelf, Antarctic Peninsula
}

\author{
H. Rott $^{1,2}$, F. Müller ${ }^{2}$, T. Nagler ${ }^{2}$, and D. Floricioiu ${ }^{3}$ \\ ${ }^{1}$ Institute of Meteorology and Geophysics, University of Innsbruck, 6020 Innsbruck, Austria \\ ${ }^{2}$ ENVEO IT GmbH, Technikerstrasse 21a, 6020 Innsbruck, Austria \\ ${ }^{3}$ German Aerospace Center, Remote Sensing Technology Institute, 82234 Wessling, Germany
}

Received: 13 August 2010 - Published in The Cryosphere Discuss.: 6 September 2010

Revised: 27 January 2011 - Accepted: 14 February 2011 - Published: 1 March 2011

\begin{abstract}
The outlet glaciers to the embayment of the Larsen-B Ice Shelf started to accelerate soon after the ice shelf disintegrated in March 2002. We analyse high resolution radar images of the TerraSAR-X satellite, launched in June 2007, to map the motion of outlet glaciers in detail. The frontal velocities are used to estimate the calving fluxes for 2008/2009. As reference for pre-collapse conditions, when the glaciers were in balanced state, the ice fluxes through the same gates are computed using ice motion maps derived from interferometric data of the ERS-1/ERS-2 satellites in 1995 and 1999. Profiles of satellite laser altimetry from ICESat, crossing the terminus of several glaciers, indicate considerable glacier thinning between 2003 and 2007/2008. This is taken into account for defining the calving cross sections. The difference between the pre- and post-collapse fluxes provides an estimate on the mass imbalance. For the Larsen-B embayment the 2008 mass deficit is estimated at $4.34 \pm 1.64 \mathrm{Gt} \mathrm{a}^{-1}$, significantly lower than previously published values. The ice flow acceleration follows a similar pattern on the various glaciers, gradually decreasing in magnitude with distance upstream from the calving front. This suggests stress perturbation at the glacier front being the main factor for acceleration. So far there are no signs of slow-down indicating that dynamic thinning and frontal retreat will go on.
\end{abstract}

\section{Introduction}

The response of grounded glacier ice to the disintegration of ice shelves is an important topic for establishing realistic scenarios on future contributions of Antarctic ice masses to

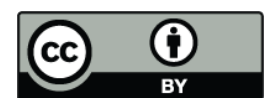

Correspondence to: $\mathrm{H}$. Rott

(helmut.rott@uibk.ac.at) sea level rise. After disintegration of the northern sections of Larsen Ice Shelf (LIS) on the Antarctic Peninsula, the outlet glaciers previously feeding the ice shelves turned into tidewater glaciers. These new boundary conditions caused major acceleration and increase of ice export, first reported by Rott et al. (2002) for Drygalski Glacier and several other glaciers calving into the Larsen-A embayment. The time scale for reaching a new equilibrium state depends on various factors, including the geometry of the glacier bed, sliding conditions, the mass supply from upper glacier reaches, and the surface mass balance. The increased velocity on the terminus of Drygalski Glacier, for example, has been maintained to date at the same level which was reached in 1999, four years after Larsen-A had disappeared (Rott et al., 2008). This is known from ice motion analysis using TerraSAR-X data acquired in 2007-2010.

The outlet glaciers at Larsen-B Ice Shelf started to accelerate soon after the northern and central ice shelf sections broke away in March 2002 (Rignot et al., 2004; Scambos et al., 2004; Riedl et al., 2005; Rott et al., 2007). Ice motion data were obtained by applying image correlation techniques in repeat pass images of various satellite sensors, namely optical imagery of Landsat (Scambos et al., 2004), and radar images of Radarsat-1 (Rignot et al., 2004) and of the Advanced Synthetic Aperture Radar (ASAR) on Envisat (Rott et al., 2007). Only few measurements are available on ice thickness and changes of surface elevation. Surface topography and glacier thinning were observed by the Geoscience Laser Altimeter System (GLAS) of NASA's ICESat along a few tracks crossing the glaciers (Scambos et al., 2004; Hulbe et al., 2008). On Crane Glacier airborne radar depth soundings were performed by the Center for Remoter Sensing of Ice Sheets (CReSIS), University of Kansas, in 2002, 2004, 2009, and 2010 (CReSIS, 2010). The 2002 campaign was performed in cooperation with Centro de Estudios Científicos, Valdivia, Chile (CECS) and NASA. The 2009

Published by Copernicus Publications on behalf of the European Geosciences Union. 
and 2010 surveys were parts of NASA IceBridge Campaigns. Bathymetric measurements were made in 2006 in the fjord in front of Crane Glacier (Zgur et al., 2007).

Improved data for the analysis of surface motion of the glaciers became available after the launch of TerraSAR-X in June 2007. The satellite delivers synthetic aperture radar (SAR) images at very high resolution and 11-day repeat cycle (Werninghaus and Buckreuss, 2010). Between June 2007 and April 2010 more than 70 SAR images were acquired by the TerraSAR-X satellite over outlet glaciers of the northeastern Antarctic Peninsula. We used this dataset to map the post-collapse flow fields of the outlet glaciers above Larsen$A$ and Larsen-B in greater detail and completeness than feasible with other satellite sensors. In this paper we focus on the study of glaciers in the Larsen-B embayment (Fig. 1).

TerraSAR-X derived glacier velocities at gates near the glacier front and estimates of ice thickness are the basis for deriving 2008/2009 calving fluxes. As ice thickness measurements are available only for Crane Glacier, the cross section at the calving gate of the other glaciers was inferred from the pre-collapse mass fluxes under the assumption of mass equilibrium conditions. For the pre-collapse period accurate ice motion data are available for 1995 and 1999, derived from interferometric repeat pass SAR (InSAR) data of the ERS-1/ERS-2 tandem mission. The stability of ice motion in 1995-1999 suggests that the glaciers were approximately in equilibrium. These mass fluxes are used as reference for estimating the mass imbalance after acceleration.

\section{Database and methods}

The flow fields for the pre-collapse state are obtained from InSAR data of the ERS-1 and ERS-2 SAR satellites acquired in 1995 and 1999 (Rack et al., 2000; Rott et al., 2002). For orthorectification of the interferograms we used the Antarctic Digital Elevation Model produced by Byrd Polar Research Center, Ohio State University (Jezek at al., 1999). InSAR enables accurate and detailed mapping of the surface velocity of glaciers and ice sheets, but requires temporal stability of the radar phase. InSAR data of the ERS-1/ERS-2 tandem mission show reasonable to good phase stability (coherence) on the LIS glaciers because of the short $(24 \mathrm{~h})$ repeat pass interval. After shutdown of ERS-1 in early 2000, only SAR systems operating at longer repeat pass intervals were available, suffering from temporal decorrelation of the radar signal due to snowfall, snow drift or surface melt.

An alternative to using InSAR for mapping ice motion is cross-correlation of templates in SAR amplitude images, also called feature tracking. This technique delivers two components of the velocity vector (slant range and azimuth). It can measure shifts at fractions of a pixel (Strozzi et al., 2002). The incoherent SAR backscatter amplitude can be employed for cross-correlation, but requires distinct and stable surface features. The technique is similar to feature tracking in opti-

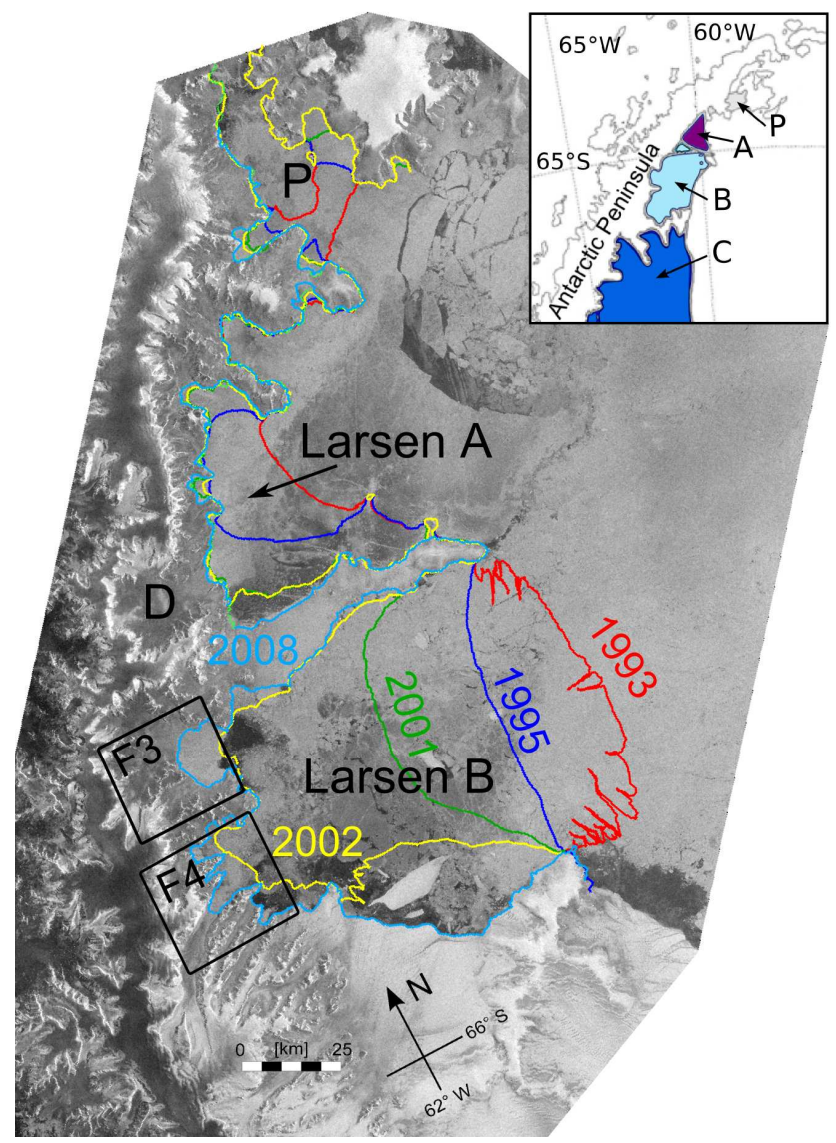

Fig. 1. Section of Envisat ASAR Wide Swath image of the northern Larsen Ice Shelf, 6 March 2008, geocoded. P - Former ice shelf in Prince Gustav Channel. Red, blue, green, yellow, cyan line: ice edge on 26 August 1993, 30 January 1995, 6 October 2001, 18 March 2002, 6 March 2008. D - Drygalski Glacier. F3, F4: location of Figs. 3, 4.

cal repeat pass imagery (Scambos et al., 2004). An advantage of SAR is the regular repeat observation capability, both in terms of time interval and illumination. Image correlation is less sensitive to surface displacement than InSAR, but this can at least partly be compensated by using repeat observations over longer time intervals. Another drawback is the lack of spatial detail compared to InSAR due to the size of the templates required for obtaining stable correlation peaks. This handicap can be largely overcome by very high resolution sensors, such as the SAR of TerraSAR-X.

We analyzed glacier motion in the years 2007 to 2010 using TerraSAR-X single-look slant-range complex (SSC) images in stripmap mode, horizontal receive and transmit $(\mathrm{HH})$ polarization, with $30 \mathrm{~km}$ swath width, acquired at different image swathes. Out of this data base we selected two swathes with the same repeat coverage as basis for computing glacier mass fluxes in 2008 and 2009 (Table 1). The spatial resolution of this product is $3.3 \mathrm{~m}$ in azimuth and $1.2 \mathrm{~m}$ in slant range at $150 \mathrm{MHz}$ chirp bandwidth (Breit et al., 2010), 
Table 1. Dates of satellite image pairs used for mapping glacier motion and estimation of mass fluxes.

\begin{tabular}{lcl}
\hline Satellite & Track/Strip & Dates \\
\hline ERS-1/ERS-2 & 018 & 7 Nov 1995/8 Nov 1995 \\
ERS-1/ERS-2 & 424 & 9 Nov 1999/10 Nov 1999 \\
TerraSAR-X & $34 / 09$ & $\begin{array}{l}\text { 13 Oct 2008/24 Oct 2008/ } \\
\text { 4 Nov 2008 }\end{array}$ \\
TerraSAR-X & $34 / 09$ & 7 Apr 2009/18 Apr 2009 \\
TerraSAR-X & $34 / 09$ & 2 Nov 2009/13 Nov 2009 \\
TerraSAR-X & $110 / 05$ & 23 Mar 2008/3 Apr 2008 \\
TerraSAR-X & $110 / 05$ & $\begin{array}{l}\text { 18 Oct 2008/29 Oct 2008/ } \\
\text { 9 Nov 2008 }\end{array}$ \\
TerraSAR-X & $110 / 05$ & $\begin{array}{l}\text { 27 Oct 2009/7 Nov 2009/ } \\
\text { 18 Nov 2009 }\end{array}$ \\
& & \\
\hline
\end{tabular}

corresponding to $2.1 \mathrm{~m}$ in ground range at 35 degree incidence angle. The pixel size, specified in the digital data sets, is $1.95 \mathrm{~m} \times 0.90 \mathrm{~m}$ (azimuth $\times$ slant range). The repeat pass interval is 11 days. In a first processing step the images are co-registered in slant-range geometry at sub-pixel accuracy. For the LIS glaciers we use a window size of $96 \times 96 \mathrm{SSC}$ pixels for template matching, which corresponds to a window covering $187 \mathrm{~m} \times 150 \mathrm{~m}$ at the surface. The accuracy of the derived displacement is about 0.5 pixels. For motion analysis spanning 11 days this corresponds to an accuracy of $0.09 \mathrm{~m} \mathrm{~d}^{-1}$ in azimuth and $0.04 \mathrm{~m} \mathrm{~d}^{-1}$ in ground range.

The 2-D output of the matcher is geometrically corrected for terrain distortion and geocoded to a $5 \mathrm{~m}$ grid referring to the UTM 20 S projection to obtain a map of horizontal ice motion. If the elevation of the surface changes during the repeat interval, this causes an additional shift in slant range which has to be taken into account when transforming the 2-D displacement to horizontal motion. ICESat repeat measurements at a cross-glacier profile $5 \mathrm{~km}$ above the flux gate on Crane Glacier show mean surface lowering of about $35 \mathrm{~m} \mathrm{a}^{-1}$ between October 2003 and March 2007. We assume a slightly lower mean subsidence rate for the total glacier area analyzed. Accordingly, in the TerraSAR-X motion analysis for Crane Glacier terminus we account for surface lowering of $8 \mathrm{~cm} \mathrm{~d}^{-1}$ (corresponding to $29 \mathrm{~m} \mathrm{a}^{-1}$ ). This corresponds to an increase in magnitude of the 2008 ice velocity in the centre of the glacier by $3 \%$ compared to the value without correction.

For the InSAR analysis in 1995 and 1999 ERS SAR images from one look direction (descending orbit) are available, yielding only one component of the velocity vector. The data show good coherence, so that an accuracy $\leq 5 \mathrm{~mm}$ in ground range displacement (across track) could be achieved. The flow direction at the gates of the main Larsen-B outlet glaciers varies within $\pm 40^{\circ}$ from the across track direction in the available SAR swathes. This causes a slight decrease in accuracy of the retrieved velocity, but the uncertainty stays

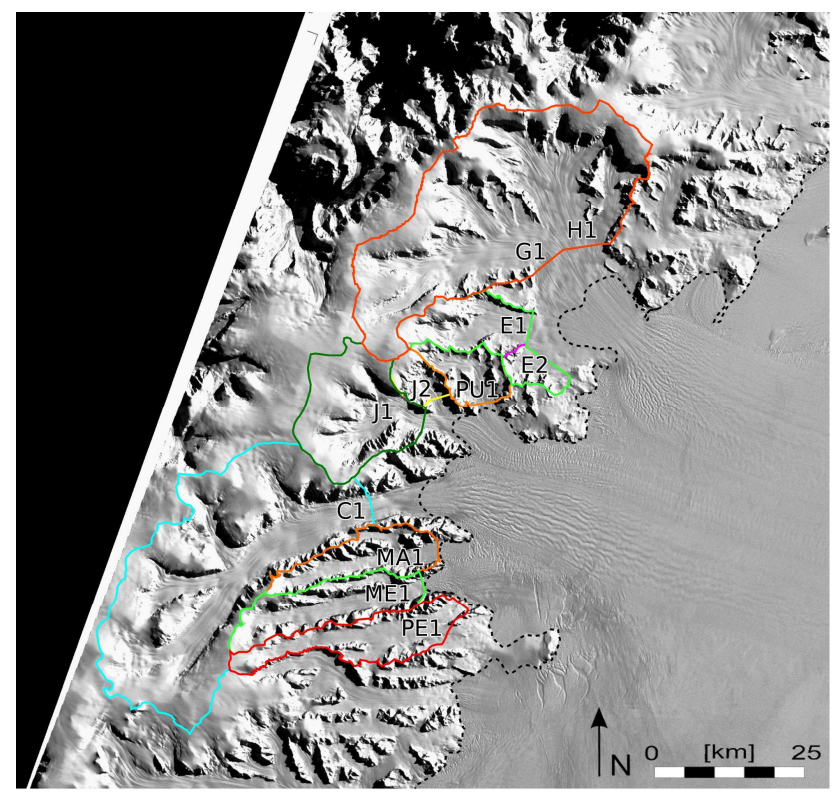

Fig. 2. Landsat Thematic Mapper Image of 1 March 1986 with boundaries of the glacier basins above Larsen-B embayment. The labels refer to the gates of the glaciers specified in Table 2. The black dotted line corresponds to the grounding line.

within $\pm 1 \mathrm{~cm} \mathrm{~d}^{-1}$. We applied the surface parallel flow assumption to derive the velocity vector. This assumption is well justified for the pre-collapse period, when the glaciers were approximately in balanced state. For level sections of a glacier, where the surface parallel flow assumption may produce spurious results, the flow direction was deduced from flow lines clearly visible in the SAR images.

The outlines of the glacier drainage basins were mapped using SAR images, Landsat images and digital elevation data. Figure 2 shows the glacier outlines in a Landsat image of 1 March 1986. Due to the slanting solar incidence the topographic features are clearly visible, as well as the flowlines on the ice shelf which at that time was still intact.

We selected gates about $1 \mathrm{~km}$ above the 2008/2009 calving front to compute the ice flux. The location of the gates is shown in TerraSAR-X images (Figs. 3 and 4). The ice flow of Hektoria, Green and Evans glaciers (H-G-E) has been the largest tributary to Larsen-B Ice Shelf before collapse, covering an area of $1580 \mathrm{~km}^{2}$. In 2003 the ice front started to retreat above the former grounding line (Riedl et al., 2005). After major retreat the terminus of Evans Glaciers separated from Hektoria-Green glaciers in 2007. By 6 March 2008 the total loss in grounded ice area of H-G-E amounted to $139 \mathrm{~km}^{2}$ referring to the pre-collapse grounding line (Sandner, 2010).

Whereas in 2008 the front of H-G-E glaciers still extended across a rather wide bay, the tongues of the other glaciers were confined in narrow valleys. Crane Glacier had lost $34 \mathrm{~km}^{2}$ of grounded ice by March 2008, with a frontal retreat 


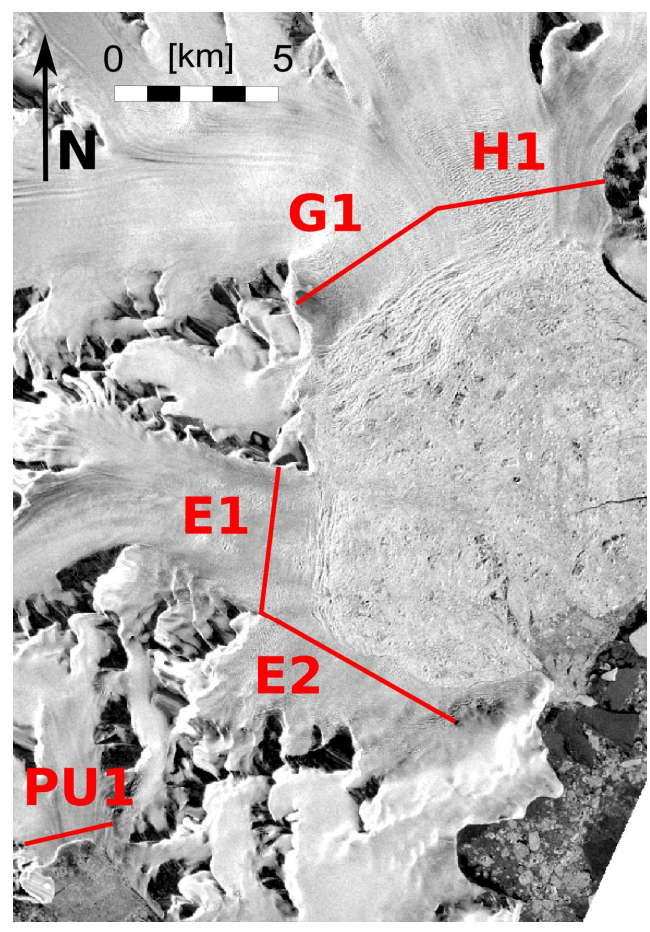

Fig. 3. TerraSAR-X image of Antarctic Peninsula glaciers draining into the northern Larsen-B embayment, acquired on 18 October 2008, with gates for mass fluxes as specified in Table 2 .

of $10 \mathrm{~km}$. Jorum Glacier lost $25 \mathrm{~km}^{2}$ of grounded ice by 6 March 2008, after splitting into two separate sections in 2005. In 2008 the front of the three southern, smaller glaciers (Pequod, Melville, Mapple) still resided near the pre-collapse grounding line. The position of the grounding line all along Larsen-A and Larsen-B ice shelf was determined by measuring tidal flexure in ERS InSAR images of 1995 and 1999 (Rack and Rott, 2004).

The ice velocity, deduced from the satellite images, is used to determine the mass flux $F$ through a transverse section $Y$ across a glacier terminus:

$F_{Y}=\rho_{\mathrm{i}} \int_{0}^{Y}\left[u_{\mathrm{m}}(y) H(y)\right] d y$

where $\rho_{\mathrm{i}}$ is the density of ice, $u_{\mathrm{m}}$ is the mean velocity of the vertical ice column and $H$ is the ice thickness. We use a column-average ice density $\rho_{\mathrm{i}}=900 \mathrm{~kg} \mathrm{~m}^{-3}$. The mean velocity can be estimated from the observed surface velocity, $u_{\mathrm{s}}$, if the deformation velocity, $u_{\mathrm{d}}$, is known. We applied the laminar flow approximation for ice deformation to estimate $u_{\mathrm{d}}$ and $u_{\mathrm{m}}$ (Paterson, 1994). For pre-collapse conditions the relation $u_{\mathrm{m}}=0.96 u_{\mathrm{s}}$ is obtained for the centre of the profile $\mathrm{C} 1$ on Crane Glacier. In 2008 the central section of the glacier front was floating.

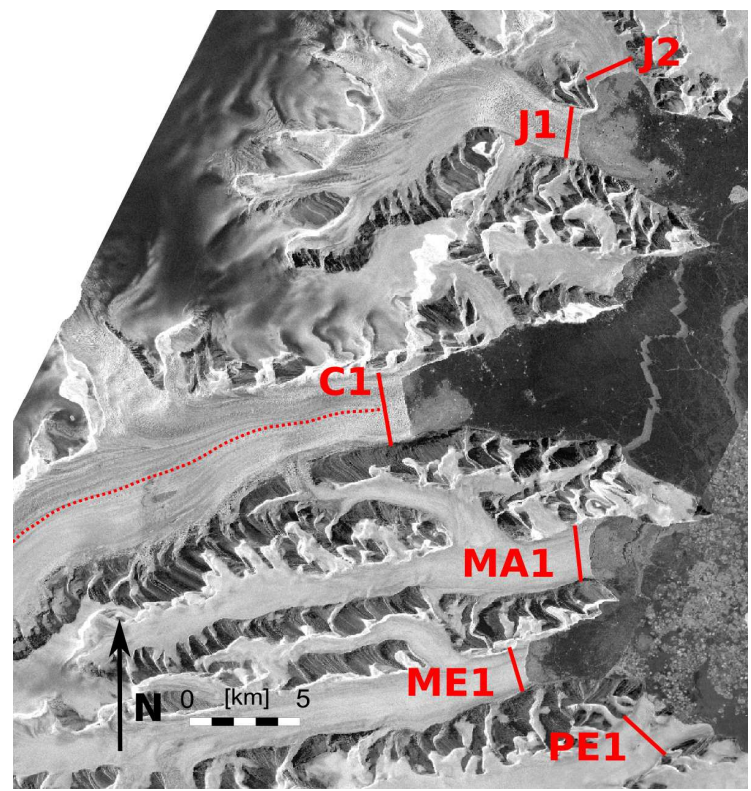

Fig. 4. TerraSAR-X image of Antarctic Peninsula glaciers draining into the central Larsen-B embayment, acquired on 18 October 2008, with gates for mass fluxes as specified in Table 2 . The dotted line shows the position of the longitudinal profile in Fig. 6 .

\section{Mass fluxes of Crane Glacier}

\subsection{Retrieval of mass fluxes}

Crane Glacier is the only glacier for which airborne ice sounding data and bathymetric data near the calving front are available. Under the assumption of stationarity during the years 1995 to 1999 the annual net mass balance, $B_{\mathrm{n}}$, can be estimated, assuming that the flux through the cross section $C 1$ equals $B_{\mathrm{n}}$ integrated over the glacier area above. According to field measurements on Larsen-B before the disintegration (Rack, 2000) and the analysis of radar backscatter signatures, the entire area of the ice shelf and tributary glaciers belonged to the percolation zone. The mean velocities across C1 differ only by 4\% in the 1995 and 1999 interferograms, with the higher value in 1995 (Fig. 5). These observations support the assumption that the glacier was close to equilibrium during the pre-collapse period. Further backup on this assumption comes from the analysis of strain rates on Larsen-B along the central flow line downstream of the glacier, based on InSAR data of 1995 to 1999 and on field measurements in 1996 and 1997 (Rack et al., 2000). Near the grounding zone no significant temporal changes of horizontal ice flow were observed, whereas the ice flow accelerated on the ice shelf towards the front indicating ice shelf thinning.

The TerraSAR-X motion analysis shows velocities of $5.1 \mathrm{~m} \mathrm{~d}^{-1}$ in the centre of $\mathrm{C} 1$ in spring (October, November) 2008, an increase by a factor of 3.4 compared to $1995 / 1999$ (Fig. 5). In late summer 2009 (April) the velocity at the front 


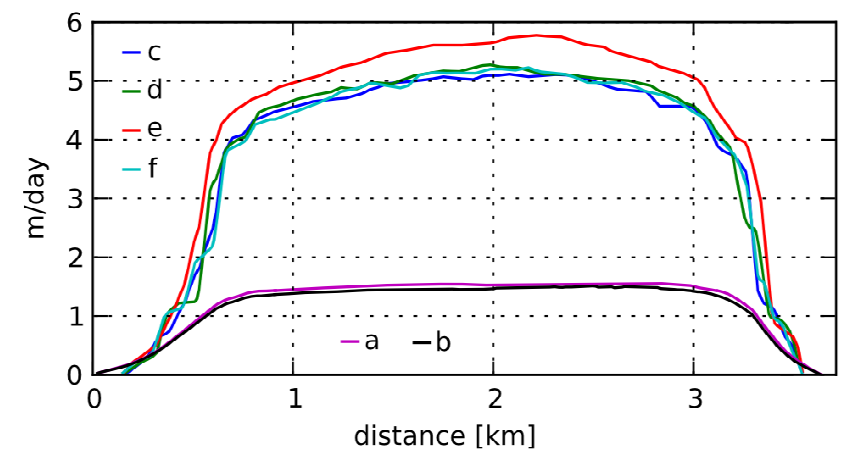

Fig. 5. Surface velocity on Crane Glacier at profile C1, derived from ERS InSAR of December 1995 (a), December 1999 (b); from TerraSAR-X of October 2008 (c), November 2008 (d), April 2009 (e), November 2009 (f).

was $10 \%$ higher than in late winter 2008, but in November 2009 similar values were measured as in October-November 2008. As evident from the longitudinal velocity profile (Fig. 6), the interim acceleration affected only the lowest $5 \mathrm{~km}$ of the terminus. In 2008 the central part of the lower terminus was already floating due to significant thinning since 2003. This suggests that the interim acceleration was triggered by changes in the stress conditions near the glacier front, probably caused by seasonal changes in sea ice conditions and water circulation in front of the glacier.

TerraSAR-X images provide evidence for such changes. In October and November 2008 and 2009 the fjord in front of the glacier was densely covered by a melange of fast sea ice and debris of glacier ice (Fig. 7). The melange moved with a velocity slightly higher than the glacier front. This contrasts with April 2009 when the bay was covered by a thin layer of fresh ice with very little glacier ice debris, which had been transported away by offshore winds.

Previous studies on Crane Glacier after ice shelf retreat used ice thickness data from a flight line along the glacier tongue measured on 26 November 2002 during the CECS/NASA campaign (Rignot et al., 2004; Hulbe et al., 2008). This flight line did not follow exactly the central flow line, crossing our profile $\mathrm{C} 1$ about half way between the centre and the northern glacier margin. A this point the CReSIS ice thickness data set shows the glacier bed at $630 \mathrm{~m}$ below and the surface at $230 \mathrm{~m}$ a.s.l. The flight lines of 2004, 2009 and 2010 do not allow a clear identification of the glacier base. Because of strong return from the canyon walls the signal response is ambiguous in several sections of the flight lines.

For this reason we do not rely on the ice sounding data but infer the glacier base of cross section $\mathrm{C} 1$ from the bathymetric map of Crane Glacier fjord, based on multi-beam echo sounder data measured in April 2006 on board the research vessel Nathaniel B. Palmer (Zgur et al., 2007). The map of the sea floor starts at a distance of $2.5 \mathrm{~km}$ from profile $\mathrm{C} 1$ and

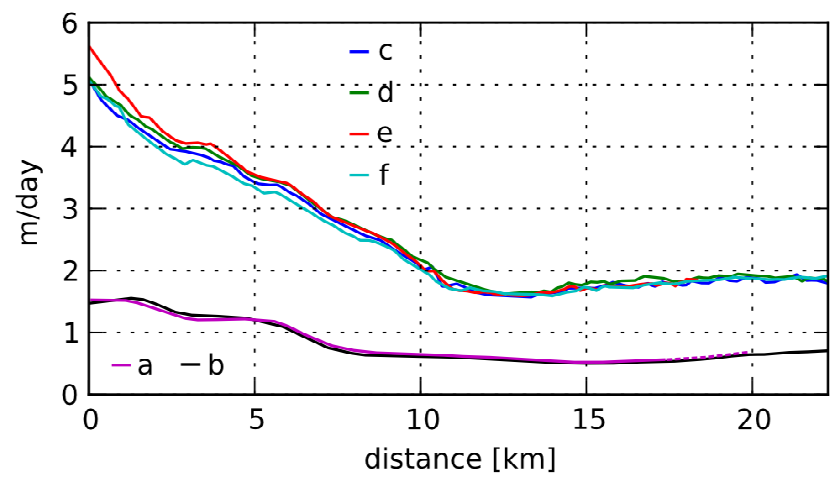

Fig. 6. Surface velocity on Crane Glacier at profile C1, derived from ERS InSAR of December 1995 (a), December 1999 (b); from TerraSAR-X of October 2008 (c), November 2008 (d), April 2009 (e), November 2009 (f).

extends from the fjord out to the Larsen-B embayment. The bottom topography is of parabolic shape, reaching a depth below $1000 \mathrm{~m}$ in three sections of the fjord. The ice motion map derived from the 1995 and 1999 InSAR data shows for a cross section $5 \mathrm{~km}$ downstream of $\mathrm{C} 1$ the same surface velocity as at $\mathrm{C} 1$. Under the assumption of mass continuity the bottom topography at these two cross sections should be similar. We use the topography of the pre-frontal cross section, shifted by $60 \mathrm{~m}$ in elevation to account for the surface slope, to define the glacier base at C1 (Fig. 1 in the Supplement). The resulting maximum depth at $\mathrm{C} 1$ is $930 \mathrm{~m}$ b.s.l., the maximum ice thickness is $1160 \mathrm{~m}$ with a surface height of $230 \mathrm{~m}$ a.s.l.

It can be assumed that the surface elevation did not change much between March 2002, the date of the ice shelf collapse, and November 2002, the time of the airborne survey, as at that time a small ice shelf section was still in place in front of the glacier. Further support for this assumption comes from ICESat elevation measurements on a profile five kilometres upstream of C1. On 23 October 2003 the elevation in the centre of the profile was $290 \mathrm{~m}$, corresponding to the airborne elevation measurement of November 2002 within the estimated uncertainty. The elevation difference of $60 \mathrm{~m}$ from the ICESat profile to $\mathrm{C} 1$ corresponds to surface inclination of 0.012 .

For computing the mass flux in 2008 thinning of the glacier has to be taken into account. An estimate of ice flux divergence at the lower terminus due to flow acceleration indicates that the central part of the glacier at $\mathrm{C} 1$ started to float three to four years after ice shelf collapse. Repeat measurements of surface topography at the ICESat profile show surface lowering by $138 \mathrm{~m}$ in the centre and $115 \mathrm{~m}$ at the margins between 23 October 2003 and 18 March 2007 (3.4 yr). We assume a similar rate of decrease in cross section area until October 2008 (5 yr) and add $10 \%$ to account for an earlier start of acceleration at $\mathrm{C} 1$. With this depletion rate the resulting glacier thickness in the central section of $\mathrm{C} 1$ is $764 \mathrm{~m}$ 


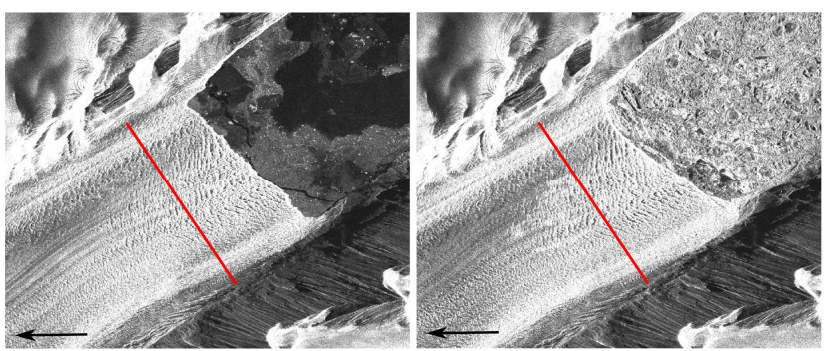

Fig. 7. Section of TerraSAR-X amplitude image of Crane Glacier terminus, 18 April 2009 (left) and 13 November 2009 (right). The arrow shows the look direction of the radar beam.

in October 2008 (used as reference date for computing the calving flux). The corresponding width of the floating section at $\mathrm{C} 1$ is $1570 \mathrm{~m}$. The TerraSAR-X images (Fig. 7) show an arching crevasse pattern, indicating a combination of simple shear near the glacier margins and longitudinal extension in the central part (Benn et al., 2007). In spite of floating the frontal position varied only by a few hundred metres between March 2006 and May 2010. The friction of the lateral, grounded glacier sections seems to be sufficient for maintaining the frontal positioning in spite of glacier thinning. The analysis of a TerraSAR-X image pair of 27 April 2010 to 8 May 2010 shows a central velocity at $\mathrm{C} 1$ of $4.7 \mathrm{~m} \mathrm{~d}^{-1}$ which is slightly lower than the 2008-2009 average. The May 2010 frontal position is shifted by only $50 \mathrm{~m}$ compared to April 2009.

\subsection{Ice discharge and net accumulation}

With these specifications for C1 the flux $F_{\mathrm{C} 1}(1995 / 1999)$ $=1.149 \pm 0.128 \mathrm{Gt} \mathrm{a}^{-1}$ is obtained using the average of the 1995 to 1999 surface velocities corrected for ice deformation. The uncertainty estimate takes into account an uncertainty of $5 \%$ in the column mean velocity over the gate and $10 \%$ uncertainty for the area of the cross section in the pre-collapse period. Thanks to the bathymetry close to the glacier front, the cross section area is rather well known.

This corresponds to a mean specific net accumulation $B_{\mathrm{a}}=1087 \pm 122 \mathrm{~kg} \mathrm{~m}^{-2} \mathrm{a}^{-1}$ for the drainage area above $\mathrm{C} 1$. No accumulation measurements are available for any of the Larsen-A and Larsen-B glaciers. For the central plateau in this region accumulation estimates are highly uncertain. The nearest field measurements of accumulation on the central peninsula plateau are reported for spots $140 \mathrm{~km}$ southwest of Crane Glacier (accumulation rate $661 \mathrm{~kg} \mathrm{~m}^{-2} \mathrm{a}^{-1}$ ) and $220 \mathrm{~km}$ north-east (accumulation rate $2478 \mathrm{~kg} \mathrm{~m}^{-2} \mathrm{a}^{-1}$ ) (Turner et al., 2002). On Larsen-B, downstream of the grounding line of Crane Glacier, field measurements at three spots revealed a mean accumulation rate of $375 \mathrm{~kg} \mathrm{~m}^{-2} \mathrm{a}^{-1}$ (Rack, 2000).

The mean net accumulation and area-altitude distribution of the glacier surface can be used to derive a scenario on el- evation dependence of net accumulation. The mean specific net accumulation of Crane Glacier basin can be reconstructed assuming an accumulation rate of $400 \mathrm{~kg} \mathrm{~m}^{-2} \mathrm{a}^{-1}$ at elevations below $200 \mathrm{~m}$, an accumulation rate of $1375 \mathrm{~kg} \mathrm{~m}^{-2} \mathrm{a}^{-1}$ above $1600 \mathrm{~m}$ (approximately the margin of the central ice plateau), and applying a linear relation between $200 \mathrm{~m}$ and $1600 \mathrm{~m}$. This elevation dependence agrees well with the elevation dependence of mean annual accumulation derived by Peel (1992) for the east coast of the Antarctic Peninsula.

In a previous study Rignot et al. (2004) derived for Crane Glacier in 1996 an outflow of $2.6 \mathrm{~km}^{3}$ ice $\mathrm{a}^{-1}$ for a gate across the grounding line, draining an area of $1193 \mathrm{~km}^{2}$. They specify a net accumulation of $2.5 \pm 0.4 \mathrm{~km}^{3}$ ice $\mathrm{a}^{-1}$, resulting in $B_{\mathrm{a}}=1886 \pm 314 \mathrm{~kg} \mathrm{~m}^{-2} \mathrm{a}^{-1}$ for ice density of $900 \mathrm{~kg} \mathrm{~m}^{-3}, 1.74$ times the value we are reporting. The reason for this difference is unclear, as no details on the assumptions for computing the mass flux are presented except the ice velocities along the central flow line which are similar to our motion data.

For computing the annual mass flux through $\mathrm{C} 1$ for 2008 we use the mean velocity of the four dates of the TerraSAR$\mathrm{X}$ analysis (Fig. 5). The mean value is based on the assumption that the $10 \%$ increased velocity observed in April 2009 persists through three months, whereas the October/November velocities are representative for nine months of the year. Full sliding is assumed, so that the surface velocity represents the mean column velocity. With the reduced cross section area due to thinning the resulting flux is $F_{\mathrm{C} 1}$ $(2008)=2.919 \pm 0.602 \mathrm{Gt} \mathrm{a}^{-1}$. In this case we assume larger uncertainty $(20 \%)$ in the cross section area.

The mass imbalance amounts to $1.770 \pm 0.614 \mathrm{Gta}^{-1}$, corresponding to a mean specific net balance of $-1675 \pm$ $581 \mathrm{~kg} \mathrm{~m}^{-2} \mathrm{a}^{-1}$. This includes the assumption that the mean net surface mass balance did not change significantly since the late 1990s. For the period 1971-2000 the mean summer temperature at the stations of the northern Antarctic Peninsula increased by $0.33^{\circ} \mathrm{C}$ per decade (Stastna, 2010). The melt contributing area comprises only the lower section of the glacier tongue, as almost all the glacier area belongs to the percolation zone. At the station Matienzo, located close to sea level on Larsen Nunatak $100 \mathrm{~km}$ north-east of the Crane Glacier front, a mean summer temperature of $-2.7^{\circ} \mathrm{C}$ has been reported for previous years (Rack, 2000; Skvarca et al., 1998). For such an environment the sum of positive air temperatures and the possible melt loss throughout summer are rather modest. For an increase of mean summer temperature by $0.5^{\circ} \mathrm{C}$ between the late 1990 s and 2008 , the increased melt contribution caused by temperature rise would correspond to less than $1 \%$ of the calving flux.

The velocity along the central flow line (Fig. 6) shows the acceleration propagating far upstream, with still 2.3-fold increase $22 \mathrm{~km}$ upstream of $\mathrm{C} 1$ at the edge of the TerraSAR-X ice motion map. With exception of $5 \mathrm{~km}$ above the front, where the April 2009 velocities were slightly increased, the velocity values are rather similar along the profile for all four 
Table 2. Drainage area, velocities at the centre line of the gate $\left(V_{\mathrm{c}}\right)$, and discharge of glaciers in the Larsen-B embayment across the gates shown in Figs. 3 and 4.

\begin{tabular}{|c|c|c|c|c|c|c|c|}
\hline \multirow[t]{2}{*}{ Glacier } & \multirow[t]{2}{*}{ Gate } & \multirow[t]{2}{*}{ Area $\left(\mathrm{km}^{2}\right)$} & \multicolumn{2}{|c|}{$V_{\mathrm{c}}\left(\mathrm{m} \mathrm{a}^{-1}\right)$} & \multicolumn{3}{|c|}{ Discharge $\left(\mathrm{Gta}^{-1}\right)$} \\
\hline & & & $1995 / 1999$ & 2008 & $1995 / 1999$ & 2008 & $\Delta$ \\
\hline Hektoria-Green & $\mathrm{H} 1, \mathrm{G} 1$ & 1091 & 387 & 1545 & 1.186 & 2.878 & $1.692 \pm 0.641$ \\
\hline Evans & $\mathrm{E} 1, \mathrm{E} 2$ & 210 & 93 & 474 & 0.144 & 0.459 & $0.315 \pm 0.099$ \\
\hline Punchbowl & PU1 & 102 & 65 & 183 & 0.058 & 0.155 & $0.097 \pm 0.034$ \\
\hline Jorum north & $\mathrm{J} 2$ & 56 & 68 & 146 & 0.042 & 0.082 & $0.040 \pm 0.019$ \\
\hline Jorum main & $\mathrm{J} 1$ & 318 & 475 & 865 & 0.346 & 0.534 & $0.188 \pm 0.131$ \\
\hline Crane & $\mathrm{C} 1$ & 1057 & 548 & 1882 & 1.149 & 2.919 & $1.770 \pm 0.614$ \\
\hline Mapple & MA1 & 165 & 46 & 82 & 0.061 & 0.109 & $0.048 \pm 0.026$ \\
\hline Melville & ME1 & 218 & 73 & 201 & 0.076 & 0.198 & $0.122 \pm 0.044$ \\
\hline Pequod & PE1 & 212 & 66 & 135 & 0.074 & 0.145 & $0.071 \pm 0.034$ \\
\hline Sum & & 3327 & & & $3.136 \pm 0.537$ & $7.479 \pm 1.542$ & $4.343 \pm 1.642$ \\
\hline
\end{tabular}

measurement periods between October 2008 and November 2009. The ongoing state of increased velocity all along the terminus suggests that the glacier is still far from a balanced state. Downwasting needs to continue for many years until the glacier adapts to the new boundary conditions. As the pre- to post-collapse velocity difference increases towards the front, mass continuity requires the thinning rate to be higher near the front and decreasing upstream. This will cause further retreat of the terminus as the grounding line of the glacier will progress farer inland.

\section{Imbalance of the calving glaciers of the Larsen-B embayment}

Whereas for Crane Glacier the pre-collapse outflow can be estimated from the observed ice velocity and cross section, this is not possible for the other glaciers due to the lack of ice thickness data. Depending on the location of the glacier relative to the ice divide of the Antarctic Peninsula, we estimate the net accumulation based on different sources or assumptions, to account for the strong west-east decrease of accumulation (Peel, 1992; Turner et al., 2002).

For glaciers flowing down from the central ice divide (Hektoria-Green glaciers, Jorum Glacier main section) we adopt the same accumulation rate as for Crane Glacier.

For estimating the mean net accumulation of the glaciers where the upper part of the accumulation area touches the main ice plateau east of the central ice divide, we use the area-altitude distribution of each individual glacier and the elevation gradient of accumulation inferred from Crane Glacier data. These are the Evans, Jorum north and Punchbowl glaciers covering a total area of $368 \mathrm{~km}^{2}$ and therefore playing a minor role for the overall mass balance of Larsen-B glaciers. The resulting mean accumulation rates range from
$569 \mathrm{~kg} \mathrm{~m}^{-2} \mathrm{a}^{-1}$ (Punchbowl Glacier) to $732 \mathrm{~kg} \mathrm{~m}^{-2} \mathrm{a}^{-1}$ (Jorum north).

The glaciers southeast of Crane Glacier (Mapple, Melville, Pequod) are separated from the main ice plateau by the deep trench of the Crane Glacier terminus. The low ice velocities in the pre-collapse phase indicate modest mass turnover. For these glaciers, which are draining through narrow valleys, we assume similar cross section geometry as for Crane Glacier. The resulting maximum ice thickness values for Mapple, Melville and Pequod glacier are $950 \mathrm{~m}, 950 \mathrm{~m}$ and $900 \mathrm{~m}$ and the inferred accumulation rates 371,347 and $350 \mathrm{~kg} \mathrm{~m}^{-2} \mathrm{a}^{-1}$.

As for Crane Glacier, the reference value for computing the pre-collapse mass flux is obtained by assuming balanced mass budget. A trapezoidal cross section is defined for the gate of each glacier matching the geometric parameters so that the pre-collapse mass flux agrees with the estimated net accumulation. The width, depth and lateral slope of each trapezoid is specified in the Supplement, Table 1. The inferred central ice thicknesses at the gates of Hectoria, Green and Evans glaciers are $350 \mathrm{~m}$ (E2), $380 \mathrm{~m}$ (E1) and $490 \mathrm{~m}$ (G1, H1). These glaciers still terminate in a wide bay, whereas the glaciers further south are flowing through narrow valleys.

The pre- and post-collapse velocities were retrieved for the main glaciers of the Larsen-B embayment (Table 2). Each of the observed glaciers accelerated significantly. The pattern of acceleration is similar as for Crane Glacier, with maximum acceleration at the front, gradually decreasing upstream. In a previous study it was presumed that the relative narrow Mapple, Melville, and Pequod glaciers have not thinned because of the rather stable position of the front (Hulbe et al., 2008). Our observations show that these glaciers are as well affected by stress-perturbation at the front after ice shelf break-up, resulting in 1.8 to 2.8 fold acceleration which should lead to thinning. The mass turnover of these glaciers is rather 


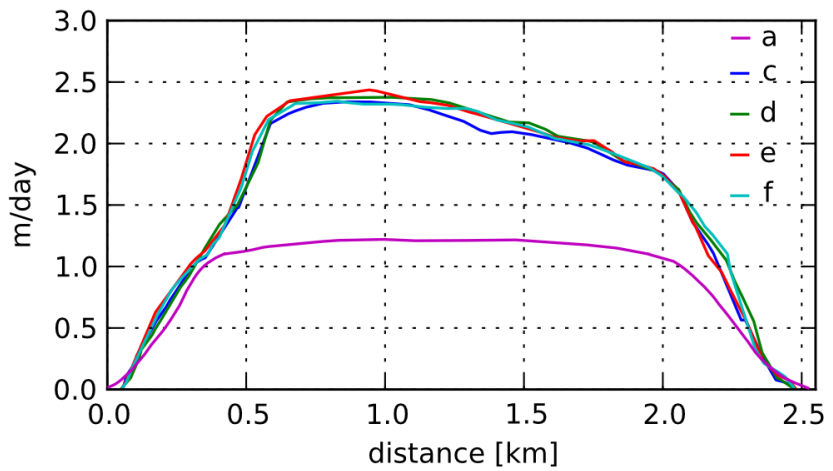

Fig. 8. Ice velocity at profile $\mathrm{J} 1$ on Jorum Glacier, derived from ERS InSAR of December 1995 (a); from TerraSAR-X of October 2008 (c), November 2008 (d), April 2009 (e), November 2009 (f).

small, the estimated thinning rates range between $1 \mathrm{ma}^{-1}$ and $4 \mathrm{~m} \mathrm{a}^{-1}$ near the glacier front.

Regarding seasonal variations in velocity, the individual glaciers behave differently. In April 2008 the velocities at the gates of Hektoria-Green glaciers and Evans Glacier were $10 \%$ higher than in October and November 2008. This is an indication of similar seasonal cycle as observed on Crane Glacier, being also related to the presence and absence of fast ice in the frontal bay. On other glaciers no significant seasonal variations were observed in the available data set. This is shown in Fig. 8 for the cross section J1 of Jorum Glacier. In the central part of J1 the flow accelerated almost two-fold since the collapse. The velocities between October/November 2008 and April 2009 differ only by 3\%.

For estimating the 2008-2009 mass flux it is necessary to account for the decrease of cross-section area due to glacier thinning. The acceleration and ice thickness at the gate is used to estimate glacier thinning for the glaciers for which no elevation data near the calving front are available in 2007 or 2008. For the main glaciers (Crane, Jorum, Hectoria, Green, Evans), which were floating, the ice thickness can be deduced from ICESat data near the front.

On 18 October 2008 an ICESat profile was measured very close to the calving front of Jorum Glacier, $700 \mathrm{~m}$ downstream of J1. Taking into account the surface slope, we obtain an elevation of $70.5 \mathrm{~m}$ in the centre of $\mathrm{J} 1$, with resulting ice thickness of $496 \mathrm{~m}$. This confirms that the lower glacier terminus was floating, in agreement with the heavily ruptured crevasse pattern. The surface of Jorum north glacier is much smoother, suggesting that the glacier was still grounded in 2008.

According to strong acceleration and large mass turnover, high thinning rates have to be expected for Hektoria, Green and Evans glaciers. On 28 November 2008 the glacier surface topography was measured by ICESat at a profile along gate E1 of Evans Glacier, showing a mean height of $38 \mathrm{~m}$ a.s.l. corresponding to ice thickness of $268 \mathrm{~m}$. We assume similar ice thickness for Hektoria and Green glaciers, as these glaciers were still connected with Evans Glacier in 2007. With an ice thickness of $268 \mathrm{~m}$ the main parts of the frontal glacier areas are floating. This agrees with the observation of major frontal retreat of the glaciers in the following years. In late summer 2009 large sections of Hektoria-Green glaciers calved off and the front retreated by several kilometres associated with further acceleration. In 2010 the fronts of the three glaciers retreated further. The velocities and mass fluxes in Table 2 refer to the period previous to these events.

The total mass deficit in 2008 for the Larsen-B glaciers is estimated at $4.34 \pm 1.64 \mathrm{Gt} \mathrm{yr}^{-1}$, corresponding to 1.4 times the net accumulation (Table 2). The total uncertainty estimate assumes $20 \%$ error of the cross section area at the calving gate for the glaciers and $5 \%$ error in velocity. For computing the mass deficit, the uncertainty is accounted twice, referring separately to the pre-collapse and post-collapse cross sections and velocities. Summing up the errors of the individual glaciers, because they may not be fully independent, results in a relative error of $37 \%$ for the total mass deficit. The mass deficit corresponds to a mean specific net balance of $b_{\mathrm{n}}=-1305 \pm$ $494 \mathrm{~kg} \mathrm{~m}^{-2} \mathrm{a}^{-1}$. The highest values of individual glaciers are holding Crane Glacier $\left(b_{\mathrm{n}}=-1675 \mathrm{~kg} \mathrm{~m}^{-2} \mathrm{a}^{-1}\right)$ followed by Hektoria-Green $\left(-1551 \mathrm{~kg} \mathrm{~m}^{-2} \mathrm{a}^{-1}\right)$ and Evans $\left(-1500 \mathrm{~kg} \mathrm{~m}^{-2} \mathrm{a}^{-1}\right)$ glaciers. On the lower end is Mapple Glacier $\left(-291 \mathrm{~kg} \mathrm{~m}^{-2} \mathrm{a}^{-1}\right)$ followed by Pequod Glacier $\left(-335 \mathrm{~kg} \mathrm{~m}^{-2} \mathrm{a}^{-1}\right)$. This sequence indicates that the glaciers with large mass turnover are most vulnerable to changing frontal stress conditions after ice shelf retreat.

It is of interest to compare the ice export across the calving gates to the mass deficit due to glacier retreat. The retreat of grounded ice area for the glaciers in the Larsen-B embayment up to 6 March 2008 amounted to $199 \mathrm{~km}^{2}$ referring to the 1995-1999 grounding line (Sandner, 2010). $70 \%$ of this retreat in area was contributed by Hektoria-Green-Evans glaciers. This ice was grounded well below sea level so that the contribution to sea level rise due to retreat of these ice masses is rather small. The mass above floating for the area between the grounding line and 2008 front (related to the pre-collapse surface topography) is estimated at $11.4 \pm 4.5 \mathrm{Gt}$ (Sandner, 2010). This corresponds to a mean annual contribution to see level rise of $1.9 \pm 0.75 \mathrm{Gt} \mathrm{a}^{-1}$ for March 2002 to March 2008.

\section{Conclusions}

Six years after ice shelf break-up the glaciers draining into the Larsen-B embayment were still far from equilibrium. On the main glaciers the central parts of the terminus near the front were floating. The ice velocity of all glaciers was significantly higher than in the pre-collapse state, showing between 1.8 and 5.1 fold increase in velocity at the calving front for the different glaciers. The acceleration reaches far upstream, with the relative change in velocity decreasing 
with distance from the calving front. This suggests that the acceleration was triggered by stress perturbation at the glacier front propagating upstream through dynamic coupling, as observed also for Greenland outlet glaciers (Nick et al., 2009). Associated dynamic glacier thinning causes increase of gravitational driving stress, decrease of basal shear stress, and eventually leads to floating and frontal retreat. Seasonal variations of velocity are rather small or absent, suggesting that melt water from the glacier surface does not play a significant role for flow dynamics. The glacier fronts will further retreat, since a mass deficit is presently observed for each of the glaciers. The rate of frontal retreat will vary for each glacier, depending on the geometry of the glacier bed and the thinning rate.

The 2008 mean specific net balance $b_{\mathrm{n}}=-1305 \mathrm{~kg}$ $\mathrm{m}^{-2} \mathrm{a}^{-1}$, ranging between $b_{\mathrm{n}}=-291 \mathrm{~kg} \mathrm{~m}^{-2} \mathrm{a}^{-1}$ and $b_{\mathrm{n}}=$ $-1675 \mathrm{~kg} \mathrm{~m}^{-2} \mathrm{a}^{-1}$ for the different Larsen-B glaciers, is comparable to the current mass deficit of mountain glaciers in mid latitudes terminating on land. The total mass balance, estimated at $B_{\mathrm{n}}=-4.34 \pm 1.64 \mathrm{Gt} \mathrm{a}^{-1}$, amounts to only $1.0 \%$ of the mean cryospheric contribution to sea level rise specified for the period 1993 to 2003 (Lemke et al., 2007).

We analyzed the flow fields and estimated the mass fluxes also for the tidewater glaciers terminating in the Larsen-A and PGC embayments, using ERS-1 tandem data of October/November 1995 and TerraSAR-X data of 2007-2009. For these glaciers we observe a similar pattern of accelerated flow as for Larsen-B. The increased velocity is maintained $15 \mathrm{yr}$ after disintegration of the ice shelves, so that thinning and frontal retreat will go on for years. Our preliminary analysis of mass fluxes, applying a similar technique as for the Larsen-B glaciers, results in a total annual mass deficit in 2008/2009 for the Larsen-A and PGC glaciers that is close to the value reported for the Larsen-B glaciers. However, the uncertainty of the mass flux analysis is higher than at LarsenB because in October 1995, the first date with InSAR ice motion data, some of the glaciers had already started to accelerate soon after the ice shelf collapse in late January 1995. Moreover, so far data on basal topography are not available for any of the glaciers.

Our estimates for the mass deficit of the glaciers in the Larsen-B embayment are much lower than reported in previous publications, both for the pre-collapse and post-collapse state. For December 2003 the estimates of mass deficit for individual glaciers in the Larsen-B embayment by Rignot et al. (2004) are between 2.9 times (Crane Glacier) and 8.3 times (Hektoria-Green-Evans glaciers) higher than our estimates for 2008. These large differences cannot be explained by deceleration. For the central flowline of Hektoria glacier (gate H1) we derived a velocity of $1420 \mathrm{~m} \mathrm{a}^{-1}$ from an Envisat Advanced Synthetic Aperture Radar (ASAR) image pair of 12 May to 16 June 2004 (Riedl at al., 2005). The velocity at this point from our 2008 TerraSAR-X analysis is $1545 \mathrm{~m} \mathrm{yr}^{-1}$. Also on other glaciers the TerraSAR-X data do not show a significant trend of decrease in flow velocity. Part of the large differences in ice export may be explained by the different positions of the flux gates and cross section areas. In late 2003 the glacier fronts were still near the previous grounding line of the ice shelf. At that time the glacier sections near the front were probably already floating due to dynamic thinning. This adds to the uncertainty in estimating the calving flux.

The differences in the estimated ice discharge of LarsenB glaciers do not matter in terms of sea level rise because of the rather small glacier area. However, for establishing realistic scenarios on glacier response to ice shelf retreat it is essential to understand the reasons for the different numbers on mass fluxes and to accurately document the time evolution of flow dynamics and glacier thinning. The new numbers on ice export of Larsen-B glaciers support the lower rate of mass deficit of the Antarctic Peninsula $\left(B_{\mathrm{n}}=-28.8 \pm 3.3 \mathrm{Gt} \mathrm{a}^{-1}\right)$ derived from GRACE gravity data of 2002-2009 by Sasgen et al. (2010), rather than the value of $B_{\mathrm{n}}=-60 \pm 46 \mathrm{Gt} \mathrm{a}^{-1}$ by Rignot et al. (2008).

\section{Supplementary material related to this article is available online at: http://www.the-cryosphere.net/5/125/2011/ tc-5-125-2011-supplement.pdf.}

Acknowledgements. We are grateful to Gino Casassa and Georg Kaser for helpful comments. Very constructive reviews and comments from Nicholas Barrand, Ted Scambos and Mauri Pelto helped to further improve the paper. This work was partly supported by the Space Application Programme (ASAP) of the Austrian Ministry of Traffic, Innovation, and Technology (BMVIT). The TerraSAR-X images were kindly made available through science project HYD039, the ERS SAR images through ESA project ERS-AO3.108 (VECTRA). The ICESat/GLAS data were obtained from NSIDC User Service, Boulder, Colorado.

Edited by: G. H. Gudmundsson

\section{References}

Benn, D. I., Warren, C. R., and Mottram, R. H.: Calving processes and the dynamics of calving glaciers, Earth-Sci. Rev., 82, 143179, 2007.

Breit, H., Fritz, T., Balss, U., Lachaise, M., Niedermeier, A., and Vonavka, M.: TerraSAR-X SAR Processing and Products, IEEE T. Geosci. Remote S., 48(2), 717-727, 2010.

CReSIS: Airborne radar depth sounder data, Antarctic data set at https://www.cresis.ku.edu/data/antarctic, at Center for Remoter Sensing of Ice Sheets, The University of Kansas, Lawrence, Kansas 66045; access: 22 December 2010.

Hulbe, C. L., Scambos, T. A., Youngberg, T., and Lamb, A. K.: Patterns of glacier response to disintegration of the Larsen B ice shelf, Antarctic Peninsula, Global Planet. Change, 63, 1-8, 2008. 
Jezek, K. C., Liu, H., Zhao, Z., and Li, B.: Improving a digital elevation model of Antarctica using radar remote sensing data and GIS techniques, Pol. Geogr., 23, 185-200, 1999.

Lemke, P., Ren, J., Alley, R. B., Allison, I., Carrasco, J., Flato, G., Fujii, Y., Kaser, G., Mote, O., Thomas, R. H., and Zhang, T.: Observations: changes in snow, ice and frozen ground, in: Climate Change 2007: The Physical Science Basis. Contribution of Working Group I to the Fourth Assessment Report of the Intergovernmental Panel on Climate Change, Cambridge Univ. Press, Cambridge, UK and New York, NY, USA, 337-383, 2007.

Nick, F. M., Vieli, A., Howat, I. M., and Joughin, I.: Large-scale changes in Greenland outlet glacier dynamics triggered at the terminus, Nat. Geosci., 2, 110-114, doi:10.1038/ngeo394, 2009.

Paterson, W. S. B.: The physics of glaciers, Third Edition, Elsevier, Oxford, 1994.

Peel, A. D.: Spatial temperature and accumulation rate variations at the Antarctic Peninsula, in: The Contribution of Antarctic Peninsula Ice to Sea Level Rise, edited by: Morris, E., 11-15, (Ice and Climate Special Report 1.), Cambridge, British Antarctic Survey, 44 pp., 1992.

Rack, W.: Dynamic behaviour and disintegration of the northern Larsen Ice Shelf, Antarctic Peninsula, Ph.D. thesis, University of Innsbruck, Austria, 166 pp., 2000.

Rack, W. and Rott, H.: Pattern of retreat and disintegration of Larsen B ice shelf, Antarctic Peninsula, Ann. Glaciol., 39, 505510, 2004

Rack, W., Doake, C. S. M., Rott, H., Siegel, A., and Skvarca, P.: Interferometric analysis of the deformation pattern of the northern Larsen Ice Shelf, Antarctic Peninsula, compared to field measurements and numerical modelling, Ann. Glaciol., 31, 205-210, 2000.

Riedl, C., Rott, H., and Rack, W.: Recent variations of Larsen Ice Shelf, Antarctic Peninsula, observed by Envisat, in: Proceedings of the 2004 Envisat and ERS Symposium, Salzburg, Austria, 610 September 2004, ESA SP-572, 6 pp., 2005.

Rignot, E., Casassa, G., Gogineni, P., Rivera, A., and Thomas, R.: Accelerated ice discharges from the Antarctic Peninsula following the collapse of the Larsen B ice shelf, Geophys. Res. Lett., 31, L18401, doi:10.1029/2004GL020697, 2004.

Rignot, E., Bamber, J. L., van den Broeke, M. R., Davis, C., Li, Y., van de Berg, W. J., and van Meijgaard, E.: Recent Antarctic ice mass loss from radar interferometry and regional climate modelling, Nat. Geosci., 1, 106-110, doi:10.1038/ngeo102, 2008.

Rott, H., Rack, W., Skvarca, P., and De Angelis, H.: Northern Larsen Ice Shelf, Antarctica: Further retreat after collapse, Ann. Glaciol., 34, 277-282, 2002.
Rott, H., Nagler, T., and Rack, W.: Increased export of grounded ice after the collapse of northern Larsen Ice Shelf, Antarctic Peninsula, observed by Envisat ASAR, Proceedings of IEEE Geoscience and Remote Sensing Symp. (IGARSS-07), 23-27 July 2007, Barcelona, Spain, 1174-1176, doi:10.1109/IGARSS.2007.4423013, 2007.

Rott, H., Nagler, T., Eineder, M., and Floricioiu, D.: New results on dynamic instability of Antarctic Peninsula glaciers detected by TerraSAR-X ice motion analysis, in: Proceedings of 7th EUSAR Conference 2008, Vol. 4, VDE Verlag, Berlin, Germany, 159162, 2008.

Sandner, R.: Ice retreat after disintegration of northern Larsen Ice Shelf, Diploma thesis, Faculty for Geo- and Atmospheric Sciences, University of Innsbruck, Austria, 97 pp., available at: http://imgi/main/publications.html, 2010.

Sasgen, I., Dobslaw, H., Martinec, Z., and Thomas, M.: Satellite gravity observation of Antarctic snow accumulation related to ENSO, Earth Planet. Sc. Lett., 299(3-4), 352-358, 2010.

Scambos, T., Bohlander, J. A., Shuman, C. A., and Skvarca, P. Glacier acceleration and thinning after ice shelf collapse in the Larsen B embayment, Antarctica, Geophys. Res. Lett., 31, L18402, 10.1029/2004GL020670, 2004.

Skvarca, P., Rack, W., Rott, H., and Donángelo, T. I.: Evidence of recent climatic warming on the eastern Antarctic Peninsula, Ann. Glaciol., 27, 628-632, 1998.

Stastna, V.: Spatio-temporal changes in surface air temperature in the region of the northern Antarctic Peninsula and south Shetland islands during 1950-2003, Polar Science, 4, 18-33, 2010.

Strozzi, T., Luckman, A., Murray, T., Wegmüller, U., and Werner, C.: Glacier motion estimation using SAR offset-tracking procedures, IEEE T. Geosci. Remote S., 40, 2384-2391, 2002.

Turner, J., Lachlan-Cope, T. A., Marshall, G. J., Morris, E. M., Mulvaney, R., and Winter, W.: Spatial variability of Antarctic Peninsula net surface mass balance, J. Geophys. Res., 107(D13), 4173, doi:10.1029/2001JD000755, 2002.

Werninghaus, R. and Buckreuss, S.: The TerraSAR-X mission and system design, IEEE T. Geosci. Remote S., 48(2), 606-614, 2010.

Zgur, F., Rebesco, M., Domack, E. W., Leventer, A., Brachfeld, S., and Willmot, V.: Geophysical survey of the thick, expanded sedimentary fill of the new-born Crane fjord (former Larsen B Ice Shelf, Antarctica), US Geological Survey and the National Academies; USGS OF-2007-1047, Extended Abstract 141, 2007. 